\title{
Rethinking diversity and difference in French language practices
}

\author{
Adam Le Nevez
}

Received: 2 May 2007/Accepted: 30 April 2008/Published online: 5 June 2008

(C) Springer Science+Business Media B.V. 2008

\begin{abstract}
This paper contributes to a debate on linguistic identity and social participation in France by providing a critical reading of language policy and practice. It challenges the notion that France is a linguistically homogenous nation where a standardised French language is universally practiced and, rather, seeks to reframe linguistic diversity and heterogeneity as fundamental and legitimate constitutive features of French society. In exploring diversity from this critical perspective, the paper looks to the ways in which a number of artists and language activists are deliberately and consciously transgressing normative notions of French to affirm the legitimacy of their alterity and difference. The paper does not make an argument against the legitimacy or social value of standard French, but rather argues in favour of a more critical and inclusive approach to cultural and linguistic difference in France.
\end{abstract}

Keywords Diversity · France $\cdot$ Language activism · Language policy · Performativity

For many of the estimated 10 million people living in France who grew up speaking a language other than French, ${ }^{1}$ linguistic diversity, plurilingualism and non-standard language practices are a living, daily reality. People speak different languages and

\footnotetext{
${ }^{1}$ Estimated in 2008 based on data from the 1999 French census. More recent data on languages spoken in France is not available.
}

A. Le Nevez (ه)

IUFM d'Alsace, Strasbourg, France

e-mail: adam.lenevez@gmail.com

A. Le Nevez

Groupes de recherche PLURIEL et GEPE (LILPA EA 1339), Université Marc Bloch,

Strasbourg, France 
they speak languages differently. However, in a country where "the mastery of French is the basis of all education" (MEN 2006, p. 13), and where considerable emphasis is placed on the reproduction of a standardised, normative practice of the national language, this diversity is seldom officially acknowledged and valorised. In a country where linguistic unity is intimately linked to a sense of collective identity, diversity and difference is frequently rendered invisible or illegitimate.

This paper is interested in the gap between policy and practice in France: on the one hand the official account of France as a linguistically unified nation and on the other the "réalités metisses qui ont fait le quotidien des francophones, dans ce territoire d'abord multilingue" (Rey 2007, p. 17). ${ }^{2}$ While non-normative language practices can be seen in negative terms: as a lack of education or linguistic competency, a stigmatising marker of social difference (Bentolila 2005; Potet $2005)$, it is also possible to see difference and diversity as a creative force, an expression of identity, a form of linguistic activism, of immanence and transgression.

At issue is not whether diversity exists, but rather the socio-symbolic value ascribed to plurilingualism and linguistic difference. Of particular interest are the ways in which the non-normative language practices of many people are positioned by a language policy that seeks to promote the practice of French universally and uniformly across the Republic, and conversely, the ways in which standard French is being transgressed as a form of activism and resistance, to express new forms of social identification.

In contrasting French language policy with a broader notion of linguistic difference, the paper proposes a view of languages as emergent and dialogic features of linguistic practice (Musk 2006, p. 88; Anward 2005, p. 31) that are constantly being enacted and recreated in performative ways (Butler 1997; Pennycook 2006). In doing so it seeks to describe the varied and often nonnormative languaging (Shohamy 2006) that people engage in as important and inclusive articulations of French linguistic identity and not as errors or deviations from a norm. To this end the paper looks at two examples of language activism in France to illustrate the ways in which language is being used as a site of social identification and critique to challenge the monopoly standard French claims in articulating legitimate French identity.

\section{Lunch in an Alsatian Kebab shop}

March 2008. I am sitting in a Turkish kebab shop in Colmar, the capital city of the department of Haut-Rhin in Alsace, France, eating lunch with some Englishspeaking colleagues. A steady stream of local workers and high school students are ordering their food from the two owners. Next to us a rowdy group of young women of North-African origin chatter in an idiomatic, colloquial French while on the television, a cable music channel plays, rather too loudly, the latest pop/hip-hop

\footnotetext{
${ }^{2}$ The realities of mixity in the daily lives of French speakers in this territory that is first and foremost multilingual.
} 
crossover clips. As I sip my Turkish yoghurt drink (made in Germany) and bite into my sandwich végétarien americain, I am struck by the linguistic and cultural diversity of the space I find myself in. Many languages can be seen or heard in this small shop, including French, English, Turkish and German, and these languages are being spoken differently by each of us: sometimes fluently, sometimes approximately and sometimes translingually. Each of us has come here with our own cultural and linguistic baggage, our own forms of signification and identification, that jostle and meld to form a momentary language ecology that will dissolve again the moment lunch is over.

As I look up to the television I am again struck by the linguistic and cultural heterogeneity of what I see. Synik, a once-edgy Parisian hip-hop artist of FrancoAlgerian origin is performing a bilingual duet with the English pop-crooner James Blunt. "I'll take everything in this life/ Je prendrais tout ce qui à prendre, les joies et les larmes" $" 3$ they each sing in their separate languages.

Beneath the images of these two men singing is a line of streaming text that audience members have sent by SMS to the television channel NRJ Hits: public dedications and declarations of love for only 35 cents plus the cost of the call. In the Kebab shop they pass ephemerally by but later that evening I find the same song repeated on the same channel and am able to record and transcribe the messages. They are fascinating, not for their content, but for their form:

"BIG DEDICASS A MES POULETTE, JVOU KIF GRAVE MES BICHETTES." says one text. "SALUT JENI CT PR TE DIR KE JTM ET KE JE VE PLU KTU MKIT JTM..." a second. "HEY J-10 AVANT LE CONCERT A MARSEILLE LE 14 MARS RDV A TT LES FANS DE TH BILL TOM GUS UND GEORG ON VOUX ATTENDS MARIONDU13" a third. "VOU POUVE PAC JLO GET RIGHT.MERCI" a fourth. ${ }^{4}$

These SMS messages are an opaque, coded and transgressive form of French, communicating intimacy and desire in the most public setting imaginable. They are clearly following their own set of grammatical and social rules, acknowledging and then flagrantly breaking standard French grammar and spelling, marking it with translingual signs of appropriation, displaying a clear, if carefully constructed, disobedience to the norm. Depending on one's viewpoint these expressions can be seen as abominations of French, or as creative expressions of social signification and difference: a scandal or a social revolution depending on the analysis.

Sitting in the kebab shop, I am reminded that France, like other countries, is a culturally and linguistically heterogeneous nation. It is a place where the linguistic

\footnotetext{
${ }^{3}$ I'll take everything there is to take, the joy and the tears.

${ }^{4}$ 1: Big dédicace à mes poulettes, je vous kiffe grave mes bichettes: A shout out to my crew, you bitches rock! 2. Salut Jeni, c'est pour te dire que je t'aime et que je veux plus que tu me quitte. Je t'aime ...: Hi Jenny, I want to tell you I love you and I don't want you to leave me again. I love you 3. Hey, J -10 [jour moins dix] avant le concert à Marseilles le 14 mars rendezvous à tous les fans de TH [Tokio Hotel] Bill, Tom, Gus und Georg on vous attends Marion du 13: Hey, 10 days to go. Before the concert in Marseille on the 14th of March rendezvous for all the fans of TH [Tokio Hotel]. Bill, Tom, Gus und Georg we are waiting for you. Marion from the 13th [department]. 4. Vous pouvez passer JLO [Jennifer Lopez] Get Right? Merci: Can you play JLO [Jennifer Lopez] Get Right? Thanks. Text transcribed from NRJ Hits 6/ 3/08, 16:41.
} 
and cultural identities of many different people interact with others, and with the lingua franca, in diverse and dialogical ways. Here the personal, the local, the national and the transnational meet, interconnect and disperse in an ongoing flow of ideas, practices, values, languages, people and products that is rarely stable or unchanging. This shop is not exceptional: it could be in any town or city in the country, and similarly diverse language contexts can be found in many different places. One only has to think of the complex, plurilingual environment of a metro station or a market place, a shopping centre, building site or playground.

The most significant issue for policy-makers and speakers alike is not whether or even why this linguistic diversity exists, but how to respond to it: should it be solicited and nurtured as a form of inclusive pluralism or rejected as a sign of nonintegration and a barrier to full social participation? Whether linguistic diversity and heterogeneity is celebrated, asserted, suppressed or ignored in public and personal contexts depends very much on the ideological position one takes and on the personal and public experiences one has with linguistic diversity. It can be experienced as a form of alienation or inclusion depending on the context in which it is framed and the extent to which those involved participate as socially empowered actors.

In the kebab shop no one else seems to notice the transgressive text messages, the musical cross-marketing or the plurilingual linguascape in which we are spending our lunch-hour. For these diners this diversity seems to pass unremarked. Perhaps they are so used to this linguistic flow that it is a normal part of daily life. Perhaps they're just not interested. Perhaps they are not conscious of the ways in which their voices contribute to this diversity or they don't see it as legitimate or significant. While many politicians and policy makers are acutely aware of the importance of language as a site of socio-symbolic power, and language is increasingly becoming a site of political engagement for activists and artists, this consciousness does not seem to be reflected, explicitly at least, in the kebab shop.

\section{Language policy, linguistic capital and the legitimacy of difference}

In the linguistic environment of the kebab shop there is no formal exigency to speak French correctly, but nor is the linguistic field neutral. Each of brings with us our own set of internalised attitudes to language, our diverse language skills and knowledge, our linguistic habitus and idiolect and our sense of linguistic appropriateness for this particular context. Consciously or unconsciously we are comparing ourselves to each other, as well as to linguistic norms, positioning ourselves according to spoken and unspoken rules of appropriateness and prestige, negotiating our place in the linguistic field.

In France the issue of language diversity and difference is extremely sensitive and finds itself at the heart of debates on social and national identity, immigration, social integration, culture, colonialism, regionalism and international relations. Despite the linguistic heterogeneity of the nation, or perhaps because of it, French language policy has for many years sought to promote a single national linguistic standard that is practiced universally and uniformly. 
French language policy had been comprehensively discussed elsewhere, particularly in Ager (1999), May (2001) and Hélot (2007). These authors describe a language policy that remains to a large degree prescriptive and protectionist, and one that is only slowly evolving to adapt to new social, political and economic imperatives, within the context of the European Union and globalisation more broadly. Within this language policy, standardised, codified and institutionalised French is clearly defined as the privileged vehicle of national identity that all citizens have the right, and the responsibility, to learn and use, if they wish to fully participate in society.

In contrast, linguistic diversity and non-normative language practices are frequently represented in negative terms, in particular as a threat to national cohesion and to the values of the Republic (Ager 1999). This threat is manifested externally, for example through "l'impérialisme de l'anglais" (Hagège 2007), ${ }^{5}$ as well as the internal threat to the purity and status of the language through incorrect usage and a perceived failure of many young people to "master" French at school (MEN 2006).

This view of French as a normative code that should be mastered and reproduced has significant consequences for speakers of other languages. The issue is particularly pertinent in relation to debates on social equity and integration in many French suburbs which are marked by high levels of social tension, unemployment, poverty and violence, as well as being the homes of large numbers of migrants and their children. In looking to explain the causes of social problems in these cités, a number of commentators, including the linguist Bentolila, suggest that the failure of schools to provide basic language skills and in particular for children to be able to read and write French correctly is an important contributing factor. Bentolila argues that a generation of disaffected suburban youth have been disadvantaged by speaking a sociolect that is lexically poor and imprecise (2005) and have been denied the opportunity for social mobility that mastering French allows. Potet goes further in arguing that the language spoken by many youths in disadvantaged French suburbs is itself a form of poverty and represents a "linguistic fracture" that quickly leads to violence and social exclusion (2005).

Learning to speak French correctly, and by implication the elimination or at least the ability to mask signs of alterity and linguistic difference, is therefore a marker of successful socio-cultural integration that leads to opportunity and social mobility. Conversely, failure to adapt to the new culture or the desire to retain one's linguistic and cultural baggage is often seen negatively, as a form of communautarisme (Taguieff 2005). Such an analyses tend therefore to focus on the competency of migrants and their children to speak French rather than on the willingness of society to adapt to the different needs of a linguistically diverse community in an inclusive fashion. The problem is represented as a lack of language skills for many people, not a lack of pluralism in society.

While this largely assimilationist view of social integration is common in France, it also has its critics. Bourdieu questions the idea that schools, and the French language, are neutral or equitable conduits to social participation $(1974,1991)$. He

\footnotetext{
5 The imperialism of English.
} 
argues that "the educational market is strictly dominated by the linguistic products of the dominant class and tends to sanction the pre-existing differences in capital" (1991, p. 62) and that to achieve this, schools "devalue popular modes of expression, dismissing them as "slang' and 'gibberish"” (1991, p. 49). In a similar vein, Hélot and Young have noted that examples of projects that promote linguistic diversity as a resource and not a handicap for schools are relatively rare and seldom attract official support, despite their potential to help pupils experience diversity and alterity as a positive source of knowledge and learning (Hélot 2003, 2007; Young and Hélot 2003).

From this alternate perspective, social exclusion and scholastic failure can be seen not (only) as the consequence of the inability (or unwillingness) of people to reproduce a normative, unmarked French appropriately, but as the consequence of an inability or unwillingness of mainstream French society to accept the diverse language skills many immigrants and their families possess as legitimate contributions to social and cultural identity. Bentolila argues that the suburban neighbourhood in which he grew up has become "un lieu ethniquement homogène, culturellement homogène, économiquement homogène, un territoire de délinquance, un désert culturel et une zone d'échec scolaire" ${ }^{\circ}$ (2005). However, this view of housing projects as homogeneous cultural deserts pays no credit to the diverse and different language and cultural practices that exist in these communities, neither in terms of the diverse language backgrounds of migrants nor the new and creative forms of language that young people speak. Rather, in rendering this difference invisible, it denies its legitimacy as a potentially meaningful act of social signification.

A key element in this question of linguistic legitimacy is the issue of how academic success and literacy are defined in plurilingual contexts. The term literacy is not commonly used in France, its nearest equivalent in educational and language policy documents being "la maîtrise de la langue française" (MEN 2006). However, the terms are not synonymous: "the mastery of French" invokes instrumentalist and functional discourses, focussing on the acquisition of a technical skill and this does not immediately address other forms of literacy, particularly critical literacy or biliteracy. In addition it explicitly refers only to French.

A focus on developing functional literacy in standard French does not therefore build on many of the language skills that children bring to class and does not help children develop a sense of critical awareness and social agency in relation to their language practices and linguistic identities. As Hélot argues, "the main educational aim is for the [immigrant] child to shift from the minority home language to the dominant majority language as early and as quickly as possible" (2003, p. 266). The aim is not to become a multilingual and critically literate actor in a linguistically diverse society, although with a different language policy and different language ideology it could be.

Seen from a critical perspective, the objective of French language policy is to regulate linguistic diversity in a hierarchy of practices (Bourdieu 1991, p. 49), with only one of these practices being marked as truly legitimate. While claiming to

\footnotetext{
${ }^{6}$ A place that is ethnically homogeneous, culturally homogeneous, economically homogeneous, a territory of delinquency, a cultural desert, a zone of scholastic failure.
} 
promote social equity, through universal access to the lingua franca, such policies are in effect promoting the legitimacy and privilege of one form of languagestandard French - and therefore limiting the status and legitimacy of other forms of language, including non-standard French dialects and idiolects, as well as regional and immigrant languages. Because speakers of these languages may not have the same ability to reproduce the legitimate, and legitimising, national standard, and because academic success is based on the successful mastery of this prestigious form, French language policy therefore has the potential to reinforce socio-linguistic inequity. One potential consequence is that many people who speak different languages and who speak languages differently, may find themselves marginalised or excluded from, rather than included in, a notion of national identity. Consequently they may find their ability to participate meaningfully in society limited.

\section{The application of performativity and transculturality to language planning and policy}

In response to the question of how to respond to linguistic heterogeneity in society, a number of writers have argued for a critical analysis not just of language policies, but of the language ideologies and epistemologies that inform these policies. In particular they bring into question the representation of languages as "finite, stable, standardized, rule-governed instrument[s] of communication" (Ricento 2006, p. 14; Shohamy 2006, p. 12) or "real objects waiting to be discovered" (Pennycook 2004, p. 3) and rather seek to view language as an imminent, dialogic process. Deleuze and Guattari suggest that languages can better be thought of in terms of difference and "an immanent process of variation" (Deleuze and Guattari 1987, p. 103). Mühlhäusler argues that in many cases language diversity is better seen as a continuum of difference rather than a patchwork of discreet languages (Mühlhäusler 1996) while for Rey "toute langue, et la nôtre, est non pas "une chose", la meilleure et la pire, mais un mouvement, un courant..." (Rey 2007, p. 15). ${ }^{7}$

The metaphor of movement and flow has been taken by Pennycook in relation to the heterogeneous and performative practice of English around the world. In his recent book "Global Englishes and transcultural flows" (2007), Pennycook explores the ways in which English language practices are frequently deliberate and conscious departures from normative notions of the language, creating new connections and fashioning new identities. English, he suggests, "is a translocal language, a language of fluidity and fixity that moves across, while becoming embedded in, the materiality of locality and social relations" (2007, p. 6). Because ideologies that privilege the prior ontological status of languages are limited in their ability to describe the diversity and creativity of many forms of language that subvert and transcend structural notions of language and identity (2007, p. 21), Pennycook argues that "we need to move beyond arguments about homogeneity or heterogeneity, or imperialism and nation-states, and instead focus on translocal and transcultural flows" (2007, pp. 5-6).

\footnotetext{
7 All language, including our own, is not "a thing", at its best and its worst, but a movement, a current.
} 
This view of language and linguistic diversity represents a shift from looking at linguistic diversity in terms of prescribing policy and planning initiatives and rather seeks to describe diversity as an ongoing social practice and a site of social signification. In this sense English, or French, can be seen not so much as a code to be coveted, mastered and judiciously managed, but as a site for the expression of different identities and for communication in diverse linguistic contexts. Pennycook (2004, 2007), following Butler (1990), argues that these language practices are performative in the sense that they are "the site where language and identity are made" (2007, p. 20). Languages, in this view, are not stable or static and do not exist prior to or independent of the signifying acts that call them into being and give them meaning. Rather, they are constantly being remade through linguistic performances and iteration.

The point here is not to argue that these standard forms of language do not exist or are not important, but rather that notions such as correctness and appropriateness that are important in defining the limits of the norm are primarily ideological, not linguistic. Notions of authenticity and appropriateness are as important as ever in these new contexts, but they take their cues from increasingly diverse social and cultural sources that are themselves in a constant process of transformation and change. Rather than ignoring non-normative linguistic and cultural forms for being too difficult, peripheral or the corruptions of a norm, a transcultural perspective refigures these linguistic and cultural forms as potentially valid, meaningful expressions of difference and identity. In this way, languages and language practices can be seen as effects, or artefacts, that emerge from a less-differentiated linguistic flow through particular socio-historical and political contexts.

A transcultural view of linguistic and cultural practice has at least two important applications for language policy and practice in France. Firstly, it provides a mechanism to describe linguistic diversity as a complex, interrelated field of social signification in terms that do not automatically represent this diversity as a hierarchy of linguistic practices. Such a model helps make explicit the socio-political nature of claims that some forms of language are more natural, correct or have greater legitimacy than others. It will clearly not stop such claims, but can help to demonstrate their inherently ideological nature.

Secondly, such an approach can help valorise and promote non-normative language practices as legitimate and potentially positive contributions to debates on national identity. By consciously and deliberately transgressing notions of appropriateness and correctness, by using language creatively and inventively, by being translingual and transcultural, activists can work to deliberately disrupt the assumed authority and privilege of the centre. In this sense, language is not simply a vehicle for activism but a potential site of activism as well.

\section{Transcultural language activism in France}

While the promotion of normative linguistic and cultural practices and the ongoing belief that heterogeneity is a threat to the identity of France may be a powerful and enduring trope, it is by no means one that is uncontested. For many French people 
whose linguistic identities extend beyond standard French, including migrants and their families, as well as speakers of regional languages, the idea of the linguistic hegemony of French is neither welcome nor representative.

For many people this diversity is simply a part of their ongoing personal lives, but for others it is important that this expression of diversity be heard publicly. In diverse and different ways a number of artists and language activists have started to challenge narrowly defined notions of language, identity and legitimacy through work that can be described as critical and transgressive. In promoting heterogeneous, translingual language spaces and practicing difference as a form of linguistic dissidence, artists such as the Breton singer Erik Marchand and the hip hop artist Diam's are using language and music in ways that consciously and deliberately challenge the legitimacy and privilege of standard French, in the process opening up a debate over how French identity is articulated.

For over 30 years the folk singer Erik Marchand has been at the forefront of a Breton cultural and linguistic revival. Marchand's music is significant for the way it helped to popularise a language that was, until the 1970s, seen by many of its speakers to be a stigmatising sign of poverty and backwardness (Winick 1995; Jones 1998; Le Coadic 1998; Gemie 2005). Marchand, along with other musicians, writers and artists, was instrumental in launching a broad cultural and linguistic revival movement that continues to this day. Through his music, and particularly by singing in Breton and Gallo, two lesser-used languages of Brittany, Marchand has helped to promote Breton as a creative signifying social practice that has a legitimate place in contemporary France.

In recent years, Marchand has begun to experiment with music that challenges and extends notions of cultural authenticity and belonging. His most recent work involves collaborations with Balkan, Romanian and traveller musicians, which explore the complex ways in which the cultural products of these diverse regions exhibit musical and linguistic similarities, as well as being sites of difference. This music includes original songs in Breton sung to traditional Balkan rhythms and melodies, Breton music played with a variety of instruments, and entirely new music that takes its inspiration from Breton, Balkan and other musical traditions.

When Marchand and the musicians he collaborates with deliberately transgress traditional notions of cultural practice, they create art that is profoundly new. The music cannot be considered entirely Breton, nor Balkan, but nor can it be summarised simply as a hybridisation or amalgam of two distinct styles. Read from a transcultural perspective, this music is performative in the sense that it challenges the notion of what Breton or Balkan music should sound like. Rather, its style and identity is created in the performance, implicating musicians and the audience alike.

When Marchand and his band played in Strasbourg recently to a diverse audience of Alsatians, Bretons, French people, Germans, Slavs and at least one Australian, the linguistic context created by the performance was truly complex. Such a space is clearly plurilingual, in the fact that many languages are simultaneously present and valorised, and it is also translingual, in the sense that frequently the boundaries of these languages are, often deliberately, blurred and crossed by speakers using language in creative ways. Not only is the band's music performative, the audience 
also engage with the performance, and each other, in ways that are spontaneous and dialogic. How does an Australian speak with a French person about contemporary traditional Breton-Balkan music they have heard in Strasbourg? What language and what communicative strategies do they use? What vocabulary do they need? What needs to be negotiated and improvised for this conversation to be meaningful? In such a space normative language practices find themselves as part of a far greater sense of diversity and cultural flow.

In his performance, Marchand was making a statement about the role of the artist to transgress notions of tradition and authenticity in order to create. Being Breton, in this sense, is not a matter of reproducing authentic cultural products, but of creating new practices informed, but not limited, by their historical context. This is a statement about the vibrancy of Breton culture-a living culture in the process of transformation, not one that is moribund, looking inwards or to a bygone cultural golden age, and not one that is subordinate to more powerful or populist French or Anglo-American influences. If Breton music challenges the notion of what can be considered a legitimate and authentic French signifying cultural practice, so too such performances help challenge, extend and disrupt the notion of what authentic Breton and Balkan linguistic and cultural forms might be.

Marchand's concert is a good example of the way cultural and linguistic heterogeneity in France is being practiced as a conscious and socially empowered way. One important difference between this heterogeneity and that experienced in the kebab shop is in its conscious expression of translingual language practices and as creative and positive performance. In the kebab shop I observed little consciousness of the diversity of the linguistic ecology: most people were seemed uninterested or unaware of their linguistic environment and their role in actively contributing to it. In contrast, Marchand's concert was a clear form of language activism, asserting the legitimacy of this cultural and linguistic heterogeneity.

A second artist whose work is transgressive is that of the French rapper Diam's. Of Greek-Cypriot-French origin, her rap is both lyrical and politicised, often speaking of social problems in the suburbs and her ideological opposition to the conservative policies of Nicolas Sarkozy and Jean-Marie Le Pen. Initially part of the hip-hop subculture, she has in recent years achieved considerable commercial success: her fourth album Dans ma bulle was the highest selling record in France in 2006 .

It can be argued that one of the reasons why Diam's has been so successful is in the way her music articulates the frequently ambiguous and conflicted desires of young French people, often from the suburbs, who both reclaim the need for social respect, recognition and affirmation, but who feel excluded from the conservative ideology of integration and respect for authority that dominate the current French political landscape. Diam's' music follows in a long line of French singers who have used music as a vehicle for political activism and also broadly engages the values and cultural forms of the hip-hop movement. In doing so, however, she frequently uses language in ways that articulate and reclaim her difference from the middle class and that locate her in a complex, transnational and translingual social space. Her music is a form of social activism, not only in her provocative lyrics that encourage people to develop a critical social consciousness, but also in the linguistic 
forms she chooses to express herself with-forms that frequently and seamlessly transgress and subvert different linguistic norms.

Consider the lyrics from Diam's' (2003) song Mon répertoire, where she locates her music within the context of the French hip hop scene through using a sophisticated mix of French, English, Spanish, hip hop vernacular, verlan ${ }^{8}$ and Parisian slang:

Moi j'veux qu'on dise que j'suis d'la bombe

Big up a ceux qui ont kiffé tout l'époque de Time Bomb

Rappelle-toi quand ca kickait sec à Paname

J'suis de l'école ou tu ne kickes pas si tu n'as pas l'âme

Concours de flow, de phase, de balle, de larme

2 Bal 2 Neg, solo ou Solaar

Un truc de fou renoi, 113 et Doudou Masta

L'époque ou y'avait peu d'bizz du rap et basta

Diam's Mon répertoire, Brut de femme (2003)

I want people to say I'm hot

Big up 9 to those who loved the Time Bomb* era

Do you remember when it 'kicked' in Paris

I'm from the school were you don't 'kick' if you don't have soul

Competitions of flow, of phases, of balls/bullets, of tears

2 Bal 2 Neg*, solo or Solaar*

A crazy black thing, 113* and Doudou Masta*

A time when rap was not big business, enough said.

(*Names of French hip hop groups, mostly from the 1990s)

Diam's' lyrics here are normative in the sense that they follow a relatively standard hip hop formula - a claim of authenticity and of talent, showing respect to her elders by placing herself within the context of their work, valorisation of the emceeing, ${ }^{10}$ skills and the good old days, before hip hop was corrupted by money and the establishment. They are also, however, transgressive and translingual. It is interesting to note the use of verlan in words such as renoi, her use of English loan-words such as "big up", "bizz" and the appropriation of the verb "to kick", with its corresponding standard French conjugations. Note too the valorisation of the concept of flow-the notion that prestige comes from mastering linguistic and cultural forms and expressions that are orally-based and that are in a constant process of transformation.

In this music there is a constant and dynamic tension between normativity and transgression. Diam's lyrics are clearly deliberate appropriations and transgressions of standard French, and other languages, but they also reproduce normative

\footnotetext{
${ }^{8}$ A form of urban slang that loosely reverses the syllabic order of certain words, for example renoi $=$ noir $($ black $)$, meuf $=$ femme $($ woman $)$.

9 A hip hop term of respect.

10 emceeing (rapping)—one of the four traditional hip hop skills with scratching (DJing), graphing (graffiti) and breaking (dancing).
} 
linguistic forms and structures. Likewise, they remain embedded within a hip hop community of practice that has its own particular codes of conduct that regulate which linguistic and cultural practices are considered prestigious and appropriate. The point is not that Diam's is seeking to destroy or abuse French; rather, her music and lyrics can be seen as a dynamic process of transgression and flow, of deterritorialisation and reterritorialisation as Deleuze and Guattari (1987) would have it. Like a graffiti artist appropriating a public wall for a piece, Diam's music is making a creative, public statement of social disobedience. This act is both deliberate (such eloquent phrasing requires great skill and linguistic dexterity) and it is politically motivated. Diam's lyrics as transgressive language acts are designed to disrupt and disturb the comfort of middle-class France with its assimilationist ideology and myth of normativity.

Ma France à moi se mélange, ouais, c'est un arc-en-ciel,

Elle te dérange, je le sais, car elle ne te veut pas pour modèle.

Diam's, Ma France à Moi Dans Ma Bulle, (2006).

My France is mixed, yeah it's a rainbow

It disturbs you, I know it, because it doesn't want you as its model

\section{Conclusion}

This paper has sought to look at language policy and practice in France and the way it treats linguistic and cultural difference through a critical lens. In seeking to describe France as fundamentally heterogeneous in terms of the linguistic and cultural practices of its citizens, my intention is to challenge the trope that the normative practice of French is a legitimate precondition for full social participation. Seen from this perspective language policies and ideologies that seek to regulate difference and diversity, and in particular policies and ideologies that seek to silence speakers by rendering their language non-normative language practices as illegitimate, can be critiqued as inequitable and politically inspired acts designed to protect the power and privilege of certain sections of society at the expense of others. Exposing the ideological positions inherent in language policy thus provides a mechanism for critically responding to these policies in creative and inclusive ways.

My aim here is not to criticise France, or French, or the French. It is not to argue that there is no place for a national standard, nor to argue that learning standard French in school is unimportant. On the contrary these language skills are essential. What is also essential, however, is to develop skills to engage critically with issues of language, power and social identity, for example through the promotion of critical literacy, language awareness and plurilingualism, so that people of all origins and backgrounds are better able to identify and respond to these issues in empowered and articulate ways, rather than experiencing diversity and difference as a form of exclusion or alienation. The work of Diam's and Marchand shows that it is possible to rethink linguistic diversity and difference as a meaningful and legitimate contribution to French identity. 


\section{References}

Anward, J. (2005). Lexeme recycled. How Categories Emerge From Interaction, Logos and Language, $V: 2,31-46$.

Ager, D. (1999). Identity, insecurity and image: France and language. Clevedon: Multilingual Matters.

Bentolila, A. (2005). Notre école a failli. Le Monde 17 November 2005.

Bourdieu, P. (1974). The school as a conservative force: Scholastic and cultural inequalities. London: Methuen.

Bourdieu, P. (1991). Language and symbolic power. Cambridge: Harvard University Press.

Butler, J. (1990). Gender trouble: Feminism and the subversion of identity. New York/London: Routledge.

Butler, J. (1997). Excitable speech: A politics of the performative. New York/London: Routledge.

Deleuze, G., \& Guattari, F. (1987). A thousand plateaus: Capitalism and schizophrenia. London: Continuum.

Diam's (2003). "Mon répertoire". Brut de femme: Universal Records.

Diam's (2006). "Ma France à moi". Dans ma bulle: Universal Records.

Gemie, S. (2005). Roots, rock Breizh: music and the politics of nationhood in contemporary Brittany. Nations and Nationalism, 11(1), 103-120. doi:10.1111/j.1354-5078.2005.00194.x

Hagège, C. (2007). La langue française est menacée. L'Humanité, 26 September 2007. http://www. humanite.fr/2007-09-26_Politique_Claude-Hagege-La-langue-francaise-est-menacee. Last accessed 14 April 2008.

Hélot, C. (2003). Language policy and the ideology of bilingual education in France. Language Policy, 2(3), 255-277. doi:10.1023/A:1027316632721

Hélot, C. (2007). Du bilinguisme en famille au plurilinguisme à l'école [From bilingualism in the family to plurilingualism in schools]. Paris: L'Harmattan.

Jones, M. C. (1998). Death of a language, birth of an identity: Brittany and the Bretons. Language problems and language planning, 22(2), 129-142.

Le Coadic, R. (1998). L'identitée bretonne [Breton identity]. Rennes: Presses Universitaires de Rennes.

May, S. (2001). Language and minority rights: Ethnicity, nationalism and the politics of language. Harlow, UK: Longman/Pearson.

MEN, Ministère de l'Education Nationale de l'Enseignement Supérieur et de la Recherche (2006). Ecole et college: tout ce que nos enfants doivent savoir[Primary School and Junior Secondary School: everything our children need to know]. Paris: CNDP.

Mühlhäusler, P. (1996). Linguistic ecology: Language change and linguistic imperialism in the Pacific region. London: Routledge.

Musk, N. (2006). Performing bilingualism in Wales with the spotlight on Welsh, Linköping Studies in Arts and Sciences 375.

Pennycook, A. (2004). Performativity and language studies. Critical Inquiry in Language Studies, 1(1), 1-26. doi:10.1207/s15427595cils0101_1

Pennycook, A. (2006). Postmodernism in language policy. In T. Ricento (Ed.), An introduction to language policy. Malden: Blackwell.

Pennycook, A. (2007). Global englishes and transcultural flows. London: Routledge.

Potet, F. (2005). Vivre avec 400 mots, Le Monde, 19 March 2005.

Rey, A. (2007). L'amour du français. Ménil-sur-l'Estrée: Editions Denoël.

Ricento, T. (2006). Theoretical perspectives in language policy. In T. Ricento (Ed.), An introduction to language policy. Malden: Blackwell.

Shohamy, E. (2006). Language policy: Hidden agendas and new approaches. London and New York: Routledge.

Taguieff, P.-A. (2005). La République enlisée. Paris: des Syrtes.

Winick, S. D. (1995). Breton folk music, Breton identity and Alan Stivell's Again. The Journal of American Folklore, 108(429), 334-354. doi:10.2307/541889

Young, A. \& Hélot, C. (2003). La diversité linguistique et culturelle à l'école : comment négocier l'écart entre les langues et les cultures de la maison et celle(s) de l'école ? In H. Hélot et al. (Eds.), Écarts de langue, écarts de culture. Frankfurt: Peter Lang. 207-225. 


\section{Author Biography}

Adam Le Nevez has worked for a number of years in various fields of language studies at universities in Australia, Thailand and France. He currently holds a research and teaching post at the Institut Universitaire de Formation des Maitres d'Alsace (IUFM d'Alsace) in Strasbourg, France where he trains primary school teachers in language awareness. He completed a $\mathrm{PhD}$ in socio-linguistics through the Faculty of Education at the University of Technology, Sydney in 2006. His work focuses on language diversity, language ecology, language ideologies of teachers and critical approaches to language policy and practice. He has most recently published on plurilingualism and the promotion of minority languages in Brittany. 